Harvard Studies in Business History XXVI

Edited by Ralph W. Hidy

Isidor Straus Professor of Business History

Graduate School of Business Administration

George F. Baker Foundation

Harvard University 


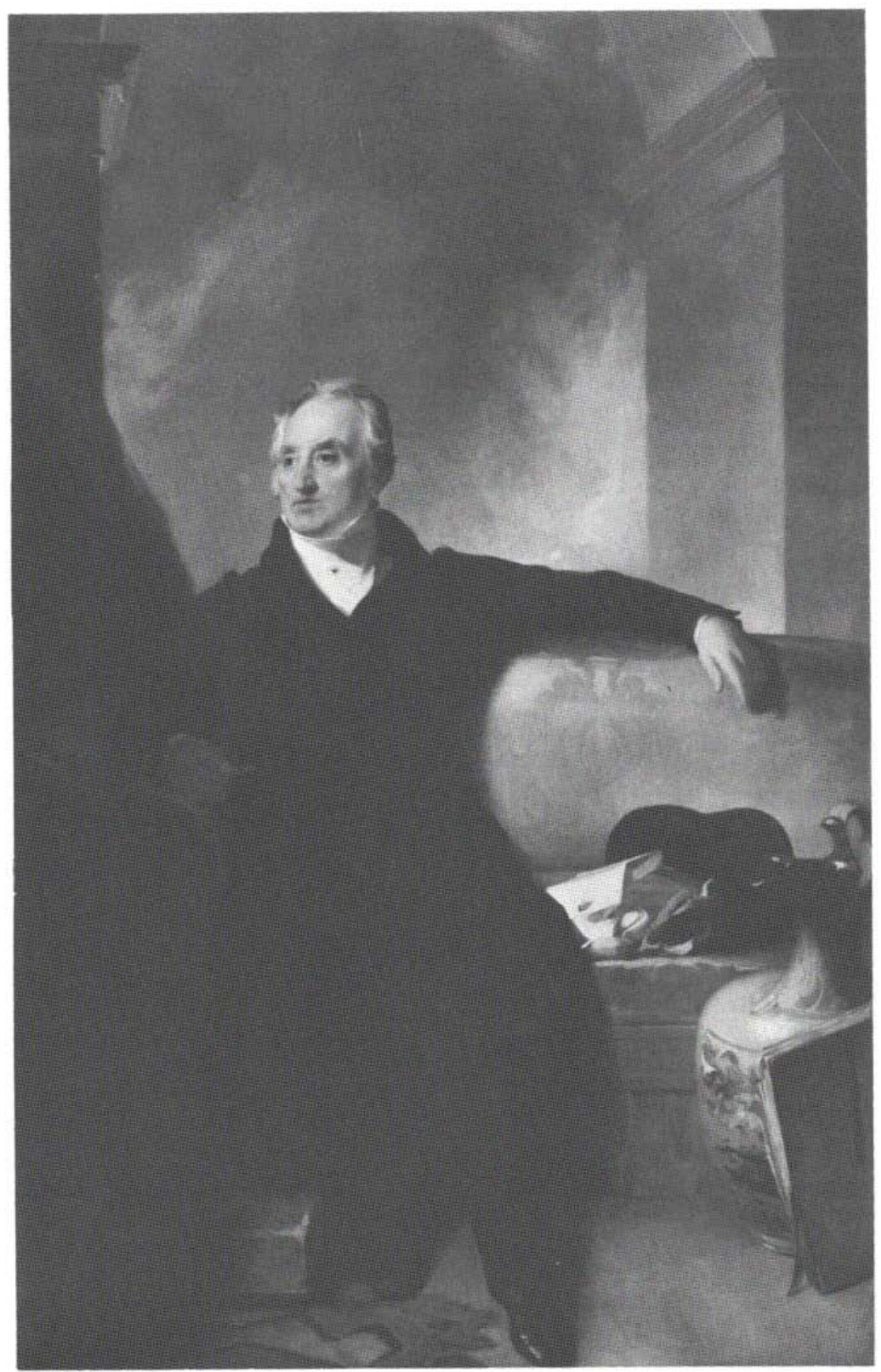

T. H. Perkins, by Thomas Sully, 1832 


\section{Merchant Prince of Boston}

Colonel T. H. Perkins, I 764-г 854

CARL SEABURG AND STANLEY PATERSON

HARVARD UNIVERSITY PRESS

Cambridge, Massachusetts / I97I 
(C) Copyright 1971 by the President and Fellows of Harvard College All rights reserved

Distributed in Great Britain by Oxford University Press, London

Library of Congress Catalog Card Number 7 I-165419

SBN 674-569ro-5

Printed in the United States of America 
To Walter Muir Whitehill

Dean of Boston Historians 
